\title{
Myopia in India
}

\author{
Amar Pujari (D), Sujeeth Modaboyina, Divya Agarwal, Gunjan Saluja, Rajeswari Thangavel, \\ Vaishali Rakheja, Rohit Saxena (D, Namrata Sharma (D), Jeewan S Titiyal, Atul Kumar \\ Dr Rajendra Prasad Centre for Ophthalmic Sciences, All India Institute of Medical Sciences, New Delhi, India
}

Correspondence: Amar Pujari, Dr Rajendra Prasad Centre for Ophthalmic Sciences, All India Institute of Medical Sciences, Room no. 2I2, RPC-I, AlIMS, New Delhi, India, Email dramarpujari@gmail.com

\begin{abstract}
India is a culturally and geographically diverse nation. Its vast demographic nature does not allow a single definition for any of the given medical conditions in its territory. One important clinical condition which has created an uproar in the rest of the world is myopia. Its cause, prevalence, etiopathogenesis and other factors are being explored constantly; however, data with respect to Indian subcontinent are genuinely missing. Hence, in this review, we enumerate the country's myopia journey from last 4 decades. The epidemiology, genetics, ocular/systemic association, quality of life, imaging, and management in myopia with necessary future directives are discussed to augment the overall management in future.
\end{abstract}

Keywords: myopia, India, myopia in India, atropine therapy in myopia, genetics and myopia, retinopathy of prematurity and myopia, imaging in myopia, management of myopia

\section{Introduction}

Myopia is a common refractive error. It is also an important cause of ocular morbidity especially in younger generations like school-going children and young adults. ${ }^{1}$ It has become a major public health problem globally, with a prediction of up to $50 \%$ of the world population will be myopic by $2050 .{ }^{2}$ Uncorrected myopia can have huge social, psychological, economic, and developmental implications. ${ }^{1}$ In addition, due to the degenerative changes in the retina and the optic disc, the irreversible vision-threatening sequel seems inevitable.

India is the second most populated country in the world, with around $41 \%$ of its population (492 million) being less than 18years of age. This young population is an important asset for the nation's development, and their challenges need to be addressed on time. While rising myopia is a cause of concern, it is not being given due importance in India due to a paucity of scientific literature in Indian set ups. ${ }^{3,4}$ Nevertheless, there is also a definitive role of genetics and environmental factors in the pathogenesis of myopia in Indian eyes; therefore, the present review aims to bridge the knowledge gap by providing a detailed report on myopia from last 40 years.

\section{Methods}

A detailed literature search was conducted on PubMed/Medline, Scopus and Web of science using the keywords "myopia", "myopia in India", "myopia prevalence", "myopia treatment", "myopia and genetics", "imaging in myopia", and "myopia and its associations". With this, more than 1000 articles were encountered, out of which only dedicated studies assessing the myopia-related entities in India eyes were included, whereas rest were excluded. A total of 113 studies satisfied our criteria, which were then assessed in detail to note their objective, clinical relevance, and conclusions. The review process was segregated into epidemiology, genetics, retinopathy of prematurity, ocular and systemic association, quality of life, imaging, and management sections for better understanding. Nevertheless, future directives were also proposed at the end to optimize future research works. 


\section{Observations}

\section{Epidemiology}

Epidemiological studies have observed the magnitude of myopia in a defined population within certain age group or in a region. India being a diverse country, every state has its own lifestyle, geography, and many other micro and macro differences, hence, the reported studies need to be analyzed on an individual basis. By keeping these views, we broadly discuss the India's myopia literature under six different regions that are relatively homogenous, these include the South zone, Central zone, East zone, West zone, North zone, and Northeast zone ${ }^{5}$ (Table 1).

\section{South Zone}

The southern states of India have a relatively well-developed medical infrastructure as compared to the rest of the country. Hence, maximum number of epidemiological studies were from this zone, here, a total of 12 studies were noted between 1997 and 2019. ${ }^{6-17}$ This can be noted in Table 1.

Of the seven studies conducted in Andhra Pradesh/Telangana, 4 were population-based, 2 were school-based and 1 was hospital-based. The prevalence in the population-based studies varied between $3.6 \%$ and $36.5 \%$, whereas the schoolbased, and the hospital-based studies had a prevalence rate of $7.5 \%$ to $8.6 \%$, and $9 \%$, respectively. ${ }^{6-12}$ To note, most of these studies included the population of less than 40 years of age except for the hospital-based studies.

Karnataka and Tamil Nadu states had 2 studies each. ${ }^{13-16}$ The prevalence rate in children between 5 and 16 years of age varied between $4 \%$ and $11.5 \%$ in the 2 school-based studies conducted in Karnataka. ${ }^{13,14}$ In Tamil Nadu's

Table I The Details of Prevalence of Myopia in India Along Various Zones

\begin{tabular}{|c|c|c|c|c|c|}
\hline $\begin{array}{l}\text { Zonal } \\
\text { Division }\end{array}$ & Reference & Place & $\begin{array}{l}\text { Type of } \\
\text { Study }\end{array}$ & $\begin{array}{l}\text { Age Group } \\
\text { (Years) }\end{array}$ & Prevalence \\
\hline \multirow[t]{12}{*}{ South Zone } & Kalikivayi ${ }^{6}(1997)$ & Hyderabad & School & $3-18$ & $8.6 \%$ \\
\hline & Dandona ${ }^{7}(1999)$ & Hyderabad & Population & - & $\begin{array}{l}4.44 \%(<15 \text { years }) \\
19.39 \%(>15 \text { years })\end{array}$ \\
\hline & Khan ${ }^{8}(2000)$ & Hyderabad & Hospital & $0-60$ & $\begin{array}{l}9 \% \text { (Degenerative } \\
\text { myopia) }\end{array}$ \\
\hline & Dandona ${ }^{9}(2002 a)$ & $\begin{array}{l}\text { Hyderabad, West Godavari, Adilabad, } \\
\text { Mahbubnagar }\end{array}$ & Population & $0-15$ & $3.6 \%$ \\
\hline & Dandona ${ }^{10}(2002 b)$ & Mahbubnagar & Population & $7-15$ & $4.1 \%$ \\
\hline & Raju ${ }^{15}(2004)$ & Thiruvallur and Kancheepuram & Population & $>39$ & $26.99 \%$ \\
\hline & Prema ${ }^{16}(2008)$ & Thiruvallur and Kancheepuram & Population & $>39$ & $\begin{array}{l}31 \% \text { (Rural) } \\
17 \% \text { (Urban) }\end{array}$ \\
\hline & Krishnaiah "'(2009) & $\begin{array}{l}\text { Hyderabad, West Godavari, Adilabad, } \\
\text { Mahbubnagar }\end{array}$ & Population & $>39$ & $36.5 \%$ \\
\hline & Uzma $^{12}$ (2009) & Hyderabad & School & $7-15$ & $7.48 \%$ \\
\hline & Bansal ${ }^{13}(20 \mid 2)$ & Kolar & School & $6-16$ & $11.5 \%$ \\
\hline & Joseph ${ }^{17}$ (2018) & Pondicherry & Population & $>39$ & $35.6 \%$ \\
\hline & Prabhu ${ }^{14}(2019)$ & Udupi & School & $5-15$ & $4 \%$ \\
\hline \multirow[t]{3}{*}{ Central } & Chandra ${ }^{18}$ (1982) & Allahabad & School & $8-16$ & $16.43 \%$ \\
\hline & $\mathrm{Haq}^{19}$ (2009) & Aligarh & Population & $>19$ & $11.5 \%$ \\
\hline & Agrawal ${ }^{20}(2020)$ & Raipur & School & $5-15$ & $3.21 \%$ \\
\hline
\end{tabular}

(Continued) 
Table I (Continued).

\begin{tabular}{|c|c|c|c|c|c|}
\hline $\begin{array}{l}\text { Zonal } \\
\text { Division }\end{array}$ & Reference & Place & $\begin{array}{l}\text { Type of } \\
\text { Study }\end{array}$ & $\begin{array}{l}\text { Age Group } \\
\text { (Years) }\end{array}$ & Prevalence \\
\hline \multicolumn{6}{|l|}{ East } \\
\hline & Datta ${ }^{22}(1983)$ & Kolkata & School & $5-13$ & $0.89 \%$ \\
\hline & $\operatorname{Das}^{23}(2007)$ & Kolkata & School & $5-10$ & $14.02 \%$ \\
\hline & Bagchi $^{24}(2008)$ & West Bengal & School & $5-15$ & $2.85 \%$ \\
\hline & Ghosh $^{25}(2012)$ & Kolkata & School & $6-14$ & $11.23 \%$ \\
\hline & $\mathrm{RaO}^{26}(2018)$ & Bhubaneswar & Hospital & $6-17$ & $24.8 \%$ \\
\hline & Warkad ${ }^{27}(2018)$ & Bhubaneswar & School & $6-17$ & $0.63 \%$ \\
\hline & Panda ${ }^{28}(2020)$ & Rayagada & School & $5-15$ & $4.9 \%$ \\
\hline \multirow[t]{4}{*}{ West } & Padhye ${ }^{29}(2009)$ & Pune & School & $5-15$ & $2.15 \%$ \\
\hline & Basu ${ }^{32}(20 I I)$ & Surat & School & $7-15$ & $13.9 \%$ \\
\hline & Nangia ${ }^{30}(2010)$ & Nagpur & Population & $>29$ & $17 \%$ \\
\hline & Jonas ${ }^{31}(2017)$ & Nagpur & Population & $>30$ & $15.3 \%$ \\
\hline \multirow[t]{6}{*}{ North zone } & Murthy ${ }^{33}(2002)$ & Delhi & Population & $5-15$ & $7.4 \%$ \\
\hline & Ahmed ${ }^{36}(2008)$ & Srinagar & School & $6-22$ & $4.74 \%$ \\
\hline & Jha ${ }^{37}(2008)$ & Leh & School & $3-15$ & $4.1 \%$ \\
\hline & Saxena ${ }^{34}(2015)$ & Delhi & School & $5-15$ & $13.12 \%$ \\
\hline & Shukla ${ }^{35}(2018)$ & Delhi & School & $9-12$ & $2.5 \%$ \\
\hline & Singh ${ }^{38}(2019)$ & Gurugram & School & $5-15$ & $21.1 \%$ \\
\hline $\begin{array}{l}\text { North East } \\
\text { zone }\end{array}$ & Natung ${ }^{39}(2017)$ & Shillong & Hospital & $5-88$ & $27.4 \%$ \\
\hline
\end{tabular}

population-based studies in the age group of more than 39 years, the prevalence rate varied between $17 \%$ and $31 \%$. ${ }^{15,16}$ In an isolated study from Pondicherry on more than 39-year-old subjects, a prevalence rate was noted to be around $35.6 \%{ }^{17}$ Nevertheless, in Prema et al observation, the prevalence rate was noted to be more in rural areas (31\%) than in urban areas (17\%). ${ }^{16}$ Hence, in brief, within the south zone states, the prevalence of myopia was variable within a variable subjective profile.

\section{Central Zone}

There were 3 studies from the central zone. ${ }^{18-20}$ Among the two Uttar Pradesh state studies, a school-based study in 816-year-old children noted a prevalence of $16.43 \%$ and a population-based study in subjects more than 19 years of age noted a prevalence of $11.5 \%{ }^{18,19}$ On the contrary, a lower prevalence of $3.21 \%$ was observed in the Chhattisgarh state's school-based study in 5-15-year-old subjects. ${ }^{20}$

\section{East Zone}

The eastern region of India had 8 studies. ${ }^{21-28}$ In West Bengal state, the prevalence in 4 school-based studies (age 5-14

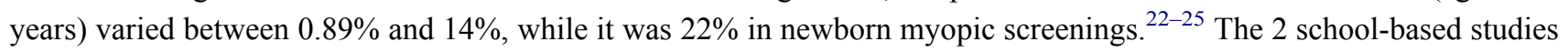
from Orissa state noted a prevalence of $0.63 \%$ to $4.9 \%$ in 5-17-year-old children, while a higher prevalence of $25 \%$ was observed in a hospital-based study in a similar age group (6-17 years). ${ }^{26-28}$ 


\section{West Zone}

The West zone had 4 studies, of which, 3 were from Maharashtra and 1 from Gujarat. ${ }^{29-32}$ The prevalence of myopia in 2 population-based studies from Maharashtra in the age group of 29 years and above was found to be $15.3 \%$ and $17 \%$. The school-based study noted a prevalence of $2.15 \%$ in $5-15$-year-old subjects. ${ }^{29,31,32}$ The Gujarat state study discovered a prevalence rate of $13.9 \%$ in $7-15$ years old subjects. ${ }^{32}$

\section{North Zone}

The north zone inherits the country's capital and had six epidemiological studies on myopia. Among these, 3 were from the national capital Delhi, 2 from Jammu and Kashmir, and 1 from the state of Haryana. ${ }^{33-38}$ The 2 school-based studies from Delhi which included 5-19-year-old subjects, documented a prevalence of myopia from $2.5 \%$ to $13 \%$. The third population-based study noted a prevalence of $7.4 \%$ in $5-15$-year-old subjects. ${ }^{33-35}$

The two studies from Jammu and Kashmir were school-based and noted a prevalence of 4.1\% to 4.74\% in 3-22-year-old subjects. ${ }^{36,37}$ The isolated school-based study from Haryana noted a prevalence of $21.1 \%$ between $5-15$-year-old subjects. ${ }^{38}$

\section{North-East Zone}

There was only one study from the northeast zone which comprises seven states. It was a hospital-based study from Meghalaya with a prevalence of $27.4 \%$ in 5-88-year-old subjects. ${ }^{39}$

\section{Genetics of Myopia in India}

Conventionally, myopia has been thought to have a polygenic inheritance with variable expressivity and a gene dosage effect. In India, the diverse geo-biological variations including genetics as well as various social factors seems to play a crucial role in the development of myopia. However, some of these factors may even be protective against myopia. Therefore, several observations have been made in Indian eyes to understand the reliable nature of genetic association in myopic eyes.

In a study from the west zone, Basu et al observed 92 families of a Shia Muslim community. A higher frequency of myopia was noted among male offspring with a consanguineous marriage history. ${ }^{40}$ In another combined study from the west and south zone, an X-linked inheritance pattern was discovered. The non-syndromic myopic mutations along pseudo-autosomal regions of distal Xq28 and other proteins were described in this study. ${ }^{41}$

From the south zone, observation on the role of Membrane frizzled-related proteins (MFRP) and the visual system homeobox protein (VSX2) gene variants showed a variable influence of these proteins on the axial lengths. ${ }^{42}$ However, a study on the role of the vitamin D receptor gene in high myopic eyes did not reveal any significant clinical associations. $^{43}$

Gupta et al conducted a study in the north zone and investigated the frequency of CYP1B1, p.E229K and p.R368H mutations in juvenile-onset open-angle glaucomatous eyes (JOAG), but they did not discover any major differences in moderate to high myopic eyes with or without such mutations. ${ }^{44}$ From Kashmir, the potential role of TGIF1 and the TGFB1 genes in myopia has been studied but again with variable significance. ${ }^{45,46}$

From the east zone, the relation between sickle cell disease and the refractive errors was investigated, where Shukla et al discovered a total of $63 \%$ prevalence of myopia in patients with sickle cell disease. Furthermore, the $L 4$ 70-bp VNTR genotype in these patients showed an increased risk for the development of refractive errors but it was statistically insignificant. However, NOS3 27-bp VNTR genotypes showed a reduced risk of myopia in these eyes. ${ }^{47}$

Hence, the association of myopia with specific genes is less clear as of now. This is because of lesser number of genetic studies as well as due to more diverse subject profile.

\section{Myopia and Retinopathy of Prematurity}

In premature babies, the incidence of refractive error is higher, myopia to be more specific. In an observation on 50 preterm babies by Verma et al, the incidence of myopia was around $16 \%$ at the end of 1 year, and this association was higher with decreasing weight. Similarly, an inverse relationship was observed between the incidence of refractive errors and gestational age. ${ }^{48}$ Since then, there have been several observations about the increased risk of myopia in babies with 
retinopathy of prematurity (ROP), both in mild and severe cases. ${ }^{4-50}$ The risk of developing myopia increased with increased clock hours of ROP, the higher number of laser spots, and prolonged regression times. ${ }^{49-51}$ Some authors found myopia to be more common in laser-treated eyes as compared to the spontaneously regressed ROP cohorts, with cicatricial retinopathy hypothesized to be a risk factor in laser-treated eyes. ${ }^{52-54} \mathrm{In}$ addition, the altered role of neuroectodermal components in ROP has been proposed to be a risk factor. ${ }^{55}$ However, concrete reasons for the development of myopia in laser-treated eyes are yet to be discovered, with the most accepted theories attributing it to steep keratometry, greater lens thickness, the forward position of the lens centre and shallow anterior chamber. ${ }^{56-58}$

\section{Myopia and Other Associations/Co-Morbidities Ocular Associations/Co-Morbidities}

It is essential to understand the ocular and systemic associations of myopia for its comprehensive management. In literature, the primarily noted association is glaucoma. In a study on congenital glaucomatous eyes operated under 1 month of age, myopia was observed in almost half of the patients. ${ }^{59}$ Due to the complex and indiscriminate changes along RNFL and optic nerve head in both myopia and glaucoma, myopia adds to the complication in the diagnosis and management of open-angle glaucoma in the later years of age. ${ }^{60}$ The glaucomatous optic disc also poses difficulties in the treatment of patients with myopic disc changes. In addition, myopia has been said to affect visual recovery in early age groups.

The second most common association was the co-existence of myopia with retino-choroidal diseases. In a study by Pan et al, it was noted that myopia and a definite change in each millimeter of axial length (AL) provided a finite protection against diabetic retinopathy and age-related macular degeneration (1.6\% in myopic eyes as compared to $3.3 \%$ in emmetropic eyes). ${ }^{61}$ A retrospective observational study to unveil the associations between central serous chorioretinopathy and myopia noted a reduced incidence of central serous chorioretinopathy in myopic eyes as compared to emmetropic eyes. ${ }^{62}$ The next common association was cataract changes in myopic eyes. Pan et al had noted a greater likelihood of nuclear cataract and posterior subcapsular cataract in myopic eyes. A finite increase in the axial length was found to be associated with subcapsular cataracts, and not with the nuclear or cortical cataracts. ${ }^{61}$ Similarly, few other studies also observed myopia to influence the development of nuclear cataracts as compared to posterior subcapsular, cortical and other forms of cataracts. ${ }^{63,64}$ A study from our centre documented the progression of unilateral axial myopia following cataract extraction in younger age groups. ${ }^{65}$

Rarer associations include the presence of myopia in blepharophimosis epicanthus inversus syndrome (BPES), variability in subjective and objective refraction in myopic eyes due to accommodative spasm and the presence of amblyopia. ${ }^{66-71}$

\section{Systemic Associations/Co-Morbidities}

Apart from ocular co-morbidities, myopia can also have systemic or syndromic associations. Myopia has been observed in beta-thalassemia patients in varying proportions, along with retinal morphological and functional changes. ${ }^{72}$ In another study, the prevalence of inherently longer eyes in taller subjects was noted (but not necessarily myopic). ${ }^{73}$ The role of prenatal sex steroid exposure as the possible cause for myopia has also been demonstrated with some evidence. ${ }^{74}$ Limited observations have shown the presence of myopia in patients with other systemic disabilities like hearing loss, cerebral palsy, down syndrome, mental retardation and learning disabilities. ${ }^{75-81}$

\section{Myopia and Quality of Life}

The children with uncorrected refractive errors are likely to face difficulty in all spheres of life, including copying text from the blackboards in classrooms. ${ }^{82}$ Myopia can also be a frequent cause of headache in children apart from school or educational-content-related concerns. ${ }^{83}$ As we know, handwriting is a visual-motor skill, and due to uncorrected or even optimally corrected refractive errors, the subjects could still face many practical difficulties during reading (due to lettersize/line variation during reading), during academic achievements and exams. Moreover, excessive near work itself can act as an aggravator for myopia progression. ${ }^{84}$ Therefore, school teachers and parents must be made aware of these difficulties, so that they can undertake quality care of the child for overall wellbeing. ${ }^{85,86}$ 
Apart from these, in Indian society, there is still a social stigma attached to spectacle usage in public. This has led to discouragement for spectacle use within emotionally weaker individuals. To address this concern, provisions for peer understanding/appreciation should be mandated to improve the overall psychological well-being of the society. Similarly, medical conditions like amblyopia, retinopathy of prematurity and other diseases must be addressed optimally before spectacle prescription. ${ }^{87,88}$ Also, the contact lens or the spectacle cost could be another barrier and as of now we do not have definite cost estimates available in India, but still, economic, and social burden are major concerns that need appropriate attention.

\section{Myopia and Ocular Imaging}

In myopic eyes, almost all the ocular tissues can be affected, and to know such clinically relevant changes, several noninvasive tests are being conducted. ${ }^{89}$ These tests are on the constant rise in recent past (Table 2).

\section{Corneal and the Anterior Scleral Imaging}

The corneal biomechanics have been stated to be altered in myopic eyes in varying proportions. ${ }^{90}$ The greater radius of corneal curvature has been attributed to longer axial lengths, lower educational levels, and the lower prevalence of high myopia. ${ }^{91}$ Apart from this, the differential thickness of anterior scleral layers (inferior $>$ superior), and its unequal change (inferior $>$ superior) with increasing myopia has also been documented. ${ }^{92}$ However, their clinical relevance in daily practice with definitive therapeutic implications are yet to be discovered.

\section{Retinal and Nerve Fiber Imaging}

The moderate ( -4 to $-8 \mathrm{D})$ and high (>-8D) myopic eyes have been observed to have progressively thinner retinal nerve fibre layer as compared to emmetropic eyes. ${ }^{93}$ Abnormally high RNFL thickness in high myopic eyes on scanning laser polarimetry has been emphasized, where false perception can change the treatment strategy. ${ }^{94}$ This becomes crucial while addressing glaucomatous eyes with myopia where RNFL thickness can hinder the accurate management of glaucoma. ${ }^{95,96}$

Associated retinal changes in the form of foveal and macular thickness variability with increasing axial length are also possible. The retinal morphology seems to be thinner with increasing axial length and myopic refractive error, but in cases of high myopia, the possibility of higher thickness must also be kept in mind as the vitreomacular tractions can lead to elevated macular/foveal thickness parameters. ${ }^{97}$ Furthermore, a vigilant and careful watch for pathological lesions irrespective of the amount of myopia is also equally important. ${ }^{98,99}$

\section{Choroidal Imaging}

Choroid like retina has also shown to possess some of the crucial vision-threatening changes. In an observation on 5-17year-old children, Matalia et al noted relatively increasing choroidal thicknesses and its volume with increasing myopia. ${ }^{100}$ And under such necessities, swept-source optical coherence tomography seems to be more reliable for choroidal imaging due to its deeper penetrating abilities. ${ }^{101}$ Overall, the tool could be of any kind, but the intention should be directed towards the identification of vision-threatening changes at the earliest. ${ }^{102}$

\section{Management of Myopia Spectacles}

Spectacles are the most accepted form of intervention for all age groups of myopia in India, and to achieve this, periodic refraction under appropriate cycloplegic agent is advocated. However, many factors are hindering the much-needed universal spectacle coverage despite adequate funding. In India, lack of easy access to regular refractive services and lack of availability of spectacles are the major concerns in resource deficient areas, and within the adequately resourced areas, lack of public interest remains the major cause of concern.

Primarily, to understand the overall spectacle need and the coverage, Marmamula et al from southern India conducted a study on more than 40-year-old subjects. They noted that, overall, only around $30 \%$ of the subjects' used spectacles for their need. ${ }^{103}$ Similarly, from northern India, Malhotra et al discovered the spectacle coverage to be around $33 \%{ }^{104}$ In 
Table 2 The Details of Imaging Studies on Myopic Eyes in India

\begin{tabular}{|c|c|c|c|c|c|c|}
\hline $\begin{array}{l}\text { S. } \\
\text { No. }\end{array}$ & Reference & $\begin{array}{l}\text { Structure } \\
\text { Analyzed }\end{array}$ & $\begin{array}{l}\text { Age } \\
\text { Group } \\
\text { (Years) }\end{array}$ & Instrument & Key Findings & Conclusion \\
\hline 1 & $\begin{array}{l}\text { Matalia } \\
\text { J et al } \\
{ }^{100} 2018\end{array}$ & $\begin{array}{l}\text { Retinal and } \\
\text { choroidal thickness } \\
\text { and volume along } \\
\text { with choroidal } \\
\text { vessel volume. }\end{array}$ & $5-17$ & $\begin{array}{l}\text { SD-OCT } \\
\text { (Optovue, Inc., } \\
\text { CA, USA) }\end{array}$ & $\begin{array}{l}\text { I.The foveal thickness, choroidal } \\
\text { volume and the choroidal vessel } \\
\text { volume had a significant increment } \\
\text { with higher degrees of myopia. }\end{array}$ & $\begin{array}{l}\text { In paediatric population, the } \\
\text { myopia has higher effects on } \\
\text { retino-choroidal changes than } \\
\text { the age. }\end{array}$ \\
\hline 2 & $\begin{array}{l}\text { Bhayana } \\
{ }^{101} \text { AA et al } \\
2019\end{array}$ & Choroidal layer. & $19-60$ & $\begin{array}{l}\text { SS-OCT (DRI- } \\
\text { OCT Triton } \\
\text { plus, } \\
\text { TOPCON, } \\
\text { Tokyo, Japan) }\end{array}$ & $\begin{array}{l}\text { I.Subfoveal choroidal thickness had } \\
\text { significant positive correlation with } \\
\text { refractive error and negative } \\
\text { correlation with axial length. }\end{array}$ & $\begin{array}{l}\text { Normative data of choroidal } \\
\text { and retinal thickness were } \\
\text { estimated using SS-OCT. }\end{array}$ \\
\hline 3 & $\begin{array}{l}\text { Dada } \\
\text { Tet al } \\
2013\end{array}$ & $\begin{array}{l}\text { Retinal nerve fiber } \\
\text { layer. }\end{array}$ & $18-40$ & $\begin{array}{l}\text { GDxVCC } \\
\text { (Carl Zeiss } \\
\text { Meditec, } \\
\text { Dublin, CA) }\end{array}$ & $\begin{array}{l}\text { I.While assessing and monitoring } \\
\text { glaucomatous damage in moderate to } \\
\text { high myopes on GDxVCC, } \\
\text { peripapillary chorioretinal atrophy and } \\
\text { scleral birefringence can contribute to } \\
\text { falsely higher RNFL values in high } \\
\text { myopic eyes. }\end{array}$ & $\begin{array}{l}\text { Myopia in glaucomatous eyes } \\
\text { need careful evaluation. }\end{array}$ \\
\hline 4 & $\begin{array}{l}\text { Singh } \\
\text { D et al } 93 \\
2017\end{array}$ & $\begin{array}{l}\text { Retinal nerve fiber } \\
\text { layer. }\end{array}$ & $20-34$ & $\begin{array}{l}\text { Cirrus HD- } \\
\text { OCT (Carl } \\
\text { Zeiss Meditec, } \\
\text { Inc., Dublin, } \\
\text { CA, USA) }\end{array}$ & $\begin{array}{l}\text { I.Emmetropic eye }(91.26 \mu) \text { had higher } \\
\text { RNFL thickness compared to } \\
\text { moderate }(83.76 \mu) \text { and high myopic } \\
\text { eyes }(78.68 \mu) .\end{array}$ & $\begin{array}{l}\text { High myopes have inherently } \\
\text { thinner RNFL, hence, } \\
\text { glaucoma in these eyes need } \\
\text { careful and comprehensive } \\
\text { approach. }\end{array}$ \\
\hline 5 & $\begin{array}{l}\text { Malakar } \\
\text { M et al } 95 \\
2015\end{array}$ & $\begin{array}{l}\text { Retinal nerve fiber } \\
\text { layer. }\end{array}$ & $11-40$ & $\begin{array}{l}\text { Fourier } \\
\text { domain OCT }\end{array}$ & $\begin{array}{l}\text { I.Mean RNFL thickness was lower in } \\
\text { high myopes }(87.89 \mu) \text { as compared to } \\
\text { the control group }(\mathrm{II} 1.64 \mu) \text {. }\end{array}$ & $\begin{array}{l}\text { Myopic eyes need special } \\
\text { consideration while } \\
\text { evaluating for glaucoma. }\end{array}$ \\
\hline 6 & $\begin{array}{l}\text { Dhakal } \\
\text { R et al } \\
{ }^{92} 2020\end{array}$ & $\begin{array}{l}\text { Anterior scleral } \\
\text { thickness. }\end{array}$ & $15-35$ & $\begin{array}{l}\text { SS-OCT } \\
\text { (Topcon, } \\
\text { Tokyo, Japan) }\end{array}$ & $\begin{array}{l}\text { I.The mean anterior sclera thickness } \\
\text { was thickest in the inferior region } \\
(605.9 \mu \mathrm{m}) \text { and thinnest in the } \\
\text { superior region }(475.3 \mu \mathrm{m}) \text {. } \\
\text { 2.And the inferior anterior scleral } \\
\text { thickness decreased with an increase } \\
\text { in degree of myopia. }\end{array}$ & $\begin{array}{l}\text { Anterior scleral thickness in } \\
\text { the inferior region can act as } \\
\text { a marker for myopia } \\
\text { progression. }\end{array}$ \\
\hline 7 & $\begin{array}{l}\text { Venkatesh } \\
\mathrm{R} \text { et al } \\
{ }^{102} 2020\end{array}$ & Choroidal layer & $18-85$ & $\begin{array}{l}\text { SD-OCT } \\
\text { (Spectralis) }\end{array}$ & $\begin{array}{l}\text { I.Intra-choroidal cavitation was seen } \\
\text { in more than half of high myopic eyes. }\end{array}$ & $\begin{array}{l}\text { The macular or peripapillary } \\
\text { intra-choroidal cavitation } \\
\text { should be screened in high } \\
\text { myopic eyes. }\end{array}$ \\
\hline 8 & $\begin{array}{l}\text { Samuel NE } \\
\text { et al }{ }^{97} 2015\end{array}$ & $\begin{array}{l}\text { Foveal and macular } \\
\text { thickness }\end{array}$ & $20-40$ & $\begin{array}{l}\text { OPTOS } \\
\text { SPECTRAL } \\
\text { OCT/SLO }\end{array}$ & $\begin{array}{l}\text { I.Low and moderate myopes had } \\
\text { thinner fovea compared to high } \\
\text { myopes. } \\
\text { 2.The axial length had a positive } \\
\text { correlation with the fovea minimum, } \\
\text { fovea and superior inner macular } \\
\text { thickness. }\end{array}$ & $\begin{array}{l}\text { Early detection of macular } \\
\text { changes can be evaluated by } \\
\text { OCT and used as a screening } \\
\text { tool in young myopes. }\end{array}$ \\
\hline
\end{tabular}


this study, further exploration revealed that around $66 \%$ of subjects did not perceive the need for glasses. ${ }^{104}$ Furthermore, Gupta et al also proposed the evidence of better spectacle coverage with subsidized prescriptions. ${ }^{105}$

In school children, Morjaria et al conducted two studies. ${ }^{106,107}$ In the first study, the differences between custom made and ready-made glasses were compared, and in the second study, novel educational interventions were evaluated apart from spectacle correction. In a later study, it was discovered that the education of the parents through phone calls and other technical means did not yield any superior results. ${ }^{107}$ Various reasons were proposed for this, of which ignorance remained the major obstacle in achieving desired results. To improve upon this, Ravilla et al highlighted a few important and viable solutions including outreach camps and community centres. ${ }^{108}$ Hence, cumulatively, these aspects need further research and critical thinking which include education and awareness about the need for spectacles, countermeasures to bullying and social humiliations, and parental education through available technology and media platforms.

\section{Orthokeratology}

The next investigated modality of treatment in myopic eyes includes orthokeratology. In general, orthokeratology means the reduction or modification or elimination of refractive error with the help of programmed contact lens application. Basically, with the use of contact lenses, the corneal curvature is changed from prolate to oblate. In a recent observation, Singh et al studied the effect of these orthokeratology lenses on 15 eyes. At the end of four months, a mean $1.2 \mathrm{D}$ of corneal flattening was observed. Moreover, the authors also reported that such users did not have any impact on the contrast sensitivity, endothelial count, axial length, and tear film parameters. ${ }^{109}$ In another prospective study on young myopes, these views were supported with favorable outcomes in 25 myopic subjects. ${ }^{110}$ Overall, the contact lens combined with other measures seems promising, but the cost and hygiene-related concerns need to be addressed before widespread suggestions are made. ${ }^{111}$

\section{Role of Atropine in Controlling the Progression of Myopia}

Atropine eye drops are another mode of therapy for myopia progression mitigation, which is being experimented and being practiced since the last decade. The initial atropine study (ATOM 1) showed the effectiveness of atropine $1 \%$ eye drops for myopia progression mitigation, and subsequently, the ATOM 2 study demonstrated comparable efficacy with lower concentrations of atropine, $0.5 \% 0.1 \%$ and $0.01 \% .{ }^{12,113}$ Indian authors have also evaluated the role of atropine eye drops in myopia. In 2017, Kothari et al evaluated the role of atropine 1\% eye drops and noted a reduction in myopia progression from $-0.6 \mathrm{D} /$ year to $-0.2 \mathrm{D} /$ year at the end of 1-year therapy. ${ }^{114}$ Apart from this, the authors also stated better effectiveness of atropine, if applied during daytime. ${ }^{114}$ In a multicentric randomized control trial, Saxena et al have found a beneficial role of $0.01 \%$ atropine drops in preventing progression of myopia in Indian school-going children aged 6-14 years. ${ }^{115}$ Similar to ATOM 2 study findings, they also found that the use of atropine caused a minimal effect on axial length elongation. The Indian myopic scenario is different from the rest of the Asia, which is due to various reasons (many are still unidentified). Hence, more detailed studies with a larger sample size are necessary. Meanwhile, apart from the routine itching and dermatitis-related concerns due to atropine usage, the other untoward events, even though rare, must also be kept in mind. ${ }^{116,117}$

\section{Refractive Surgery}

Besides, contact lenses, refractive surgeries are the other popular and significant modes of visual rehabilitation in myopic eyes. Various observations have been conducted to predict the outcome of these surgeries on visual quality.

\section{Corneal Surgical Interventions}

The corneal interventions include photorefractive keratectomy (PRK), laser in situ keratomileusis (LASIK) and the femtosecond laser-assisted small incision lenticule extraction (SMILE) procedure. These do not cure myopia, but they only help in focusing the light rays without the need for an additional optical supplement like glasses. In Indian myopic eyes, an equal efficacy between wavefront-optimized and topography-guided customized ablation has been observed. ${ }^{118}$ Similarly, to prevent flap-related complications of LASIK, flapless procedures like SMILE and PRK have been compared and have found comparable results (even though differences existed in higher-order aberrations). ${ }^{119}$ 


\section{Posterior Chamber/Phakic Intraocular Lens-Based Interventions}

In cases where corneal-based interventions are not viable, the intraocular lens-based procedures are followed, and in recent times, these interventions are also on the rise. The phakic intraocular lens implantation has several advantages over kerato-refractive procedures, including a lower incidence of higher-order aberrations, less retinal image changes, reversibility of the procedure and better contrast sensitivity. In general, Implantable Collamer Lenses (ICL) have been noted to be safe and effective in long-term management of moderate to high myopia. ${ }^{120,121}$

In 2012, Titiyal et al studied the role of iris-fixated intraocular lenses in 85 moderate to high myopic eyes. At the end of 4 years, the refractive outcomes were stated to be fairly predictable. ${ }^{122}$ Since then, several authors have evaluated the ICL as well as the Implantable phakic contact lenses (IPCL) in various circumstances and have observed promising results with both the variants. In addition, with Indian lenses, the economic feasibility and as an alternate treatment option has been highlighted including safety concerns. ${ }^{123-125}$

\section{Alternate Therapies for Myopia Yoga and Bate's Eyes Exercises}

In India, based on the evidence, various ocular exercises have been advised to improve the overall health of the eyes (Trataka Yoga, Kriya, Bates exercises and others). The near to far shifting, palming, solarization, eyewash, eyesqueezing, eye circles, eye massage and other exercises are advised. These exercises are said to act by relaxing the ocular tissues and improving their circulation. Few authors have tested these exercises on myopic eyes, and they have discovered variable or less significant evidences. As of now, the evidence is very sparse; therefore, critical thinking and future explorations are necessary to check if these modes have any effect on myopic progression. ${ }^{126-129}$

\section{Limitations}

The current review inherits the following limitations.

- The homogeneity among studies to state the prevalence in uniform terms was lacking. Hence, this considerably hampered the representation of many results.

- The heterogeneity of population made any assessment or results applicable more accurately only to the local region where it has been undertaken.

- The current social and smart technologies have seemed to become a bane rather than a boon in some respects.

- In all sectors of myopia, larger sample size studies were lacking.

\section{Conclusions}

To conclude, myopia in India and its understandings are evolving. The diverse nature of the country has differing prevalence rates, and the technological advancement has unequivocally added many novel insights including its genetics, imaging, morbidities, and management. However, due to lack of public awareness, social stigmatization, bullying, and lack of personal care the intended goals have not been achieved yet. Therefore, future research and policies need to be undertaken to address the existing limitations with novel concepts so that the future crisis can be handled better.

\section{Future Direction}

Myopia is an emerging major public health problem globally as well as in India. It needs to be tackled in time with adequate preventive and curative measures, to minimize its impact in every aspect of life. Various encouraging steps have been taken; however, these tasks need further push to achieve the desired goals. The future directives for the same are as follows.

- Prospective cohort-based studies are necessary to understand the natural history, progression, genetic influences, regional differences, and various effects of interventional measures. In addition, standardized methodology including case definition, sampling strategy and measurement protocols are to be followed to prevent potential bias. 
- Considering the influence of the internet, social media and television media in India, sensitization of the public and the target adolescents is the need of the hour now.

- Peer bullying and social stigmatization needs to be addressed with appropriate measures so as to prevent unnecessary psychological stress among the subjects.

- Indigenous innovations including smartphone technology and artificial intelligence need to be harnessed for various screening programs, education, and reminders.

- The addictive nature of smartphone usage and their possible adverse ocular effect in certain vulnerable groups also need to be emphasized.

- Urbanization is a need as well as a risk factor for myopia in India in future. It is difficult to convey solutions to both in one statement, hence future observations and regular assessments are necessary to have a dynamic approach.

- Future policies on myopia in India must be framed based on studies in India with the world picture as a guide.

\section{Disclosure}

The authors report no conflicts of interest for this work.

\section{References}

1. Congdon N, Burnett A, Frick K. The impact of uncorrected myopia on individuals and society. Commun Eye Health. 2019;32(105):7-8.

2. Holden BA, Fricke TR, Wilson DA, et al. Global prevalence of myopia and high myopia and temporal trends from 2000 through 2050. Ophthalmology. 2016;123(5):1036-1042. doi:10.1016/j.ophtha.2016.01.006

3. Agarwal D, Saxena R, Gupta V, et al. Prevalence of myopia in Indian school children: meta-analysis of last four decades. PLoS One. 2020;15 (10):e0240750. doi:10.1371/journal.pone.0240750

4. Saxena R, Vashist P, Tandon R, et al. Incidence and progression of myopia and associated factors in urban school children in Delhi: the North India Myopia Study (NIM Study). PLoS One. 2017;12(12):e0189774. doi:10.1371/journal.pone.0189774

5. Zonal Councils; 2012. Available from: https://web.archive.org/web/20120508170915/http://interstatecouncil.nic.in/zonal.htm. Accessed January 10, 2022.

6. Kalikivayi V, Naduvilath TJ, Bansal AK, Dandona L. Visual impairment in school children in southern India. Indian J Ophthalmol. 1997;45 (2):129-134

7. Dandona R, Dandona L, Naduvilath TJ, Srinivas M, McCarty CA, Rao GN. Refractive errors in an urban population in Southern India: the Andhra Pradesh Eye Disease Study. Invest Ophthalmol Vis Sci. 1999;40(12):2810-2818.

8. Khan SA. A retrospective study of low-vision cases in an Indian tertiary eye-care hospital. Indian J Ophthalmol. 2000;48(3):201-207.

9. Dandona R, Dandona L, Srinivas M, Giridhar P, McCarty CA, Rao GN. Population-based assessment of refractive error in India: the Andhra Pradesh eye disease study. Clin Experiment Ophthalmol. 2002;30(2):84-93. doi:10.1046/j.1442-6404.2002.00492.x

10. Dandona R, Dandona L, Srinivas M, et al. Refractive error in children in a rural population in India. Invest Ophthalmol Vis Sci. 2002;43 (3):615-622.

11. Krishnaiah S, Srinivas M, Khanna RC, Rao GN. Prevalence and risk factors for refractive errors in the South Indian adult population: the Andhra Pradesh Eye disease study. Clin Ophthalmol Auckl NZ. 2009;3:17-27.

12. Uzma N, Kumar BS, Khaja Mohinuddin Salar BM, Zafar MA, Reddy VD. A comparative clinical survey of the prevalence of refractive errors and eye diseases in urban and rural school children. Can J Ophthalmol J Can Ophtalmol. 2009;44(3):328-333. doi:10.3129/109-030

13. Bansal A, Krishnappa K, Datti NP, Guruprasal BS, Guha J. Ocular morbidity in school going children of Kolar district South India. $J$ Clin Biomed Sci. 2012;2(4):175-183.

14. Prabhu AV, Ve RS, Talukdar J, Chandrasekaran V. Prevalence of visual impairment in school- going children among the rural and urban setups in the Udupi district of Karnataka, India: a cross-sectional study. Oman J Ophthalmol. 2019;12(3):145-149. doi:10.4103/ojo.OJO_190_2018

15. Raju P, Ramesh SV, Arvind H, et al. Prevalence of refractive errors in a rural South Indian population. Invest Ophthalmol Vis Sci. 2004;45 (12):4268-4272. doi:10.1167/iovs.04-0221

16. Prema R, George R, Sathyamangalam Ve R, et al. Comparison of refractive errors and factors associated with spectacle use in a rural and urban South Indian population. Indian J Ophthalmol. 2008;56(2):139-144. doi:10.4103/0301-4738.39119

17. Joseph S, Krishnan T, Ravindran RD, et al. Prevalence and risk factors for myopia and other refractive errors in an adult population in southern India. Ophthalmic Physiol Opt J Br Coll Ophthalmic Opt Optom. 2018;38(3):346-358. doi:10.1111/opo.12447

18. Chandra DB, Swarup D, Srivastava RK. Prevalence and pattern along with socio-economic factors of myopia in school going children-8 to 16 years. Indian J Ophthalmol. 1982;30(6):517.

19. Haq I, Khan Z, Khalique N, Amir A, Jilani FA, Zaidi M. Prevalence of common ocular morbidities in adult population of Aligarh. Indian J Commun Med. 2009;34(3):195-201. doi:10.4103/0970-0218.55283

20. Agrawal D, Sahu A, Agrawal D. Prevalence of ocular morbidities among school children in Raipur district, India. Indian J Ophthalmol. 2020;68 (2):340-344. doi:10.4103/ijo.IJO_1454_19

21. Mukherji R, Seal SC. An epidemiological study of refractive errors among college students in Calcutta. J Indian Med Assoc. 1979;73(910):159-164.

22. Datta A, Choudhury N, Kundu K. An epidemiological study of ocular condition among primary school children of Calcutta Corporation. Indian J Ophthalmol. 1983;31(5):505-510.

23. Das A, Dutta H, Bhaduri G, De sarkar A, Sarkar K, Bannerjee M. A study on refractive errors among school children in Kolkata. J Indian Med Assoc. 2007;105(4):169-172. 
24. Bagchi K, Sarkar SN, Chattopadhyaya T, Dan A. Vision screening programme among school children-evaluation of the outcome in a selected urban locality. J Indian Med Assoc. 2008;106(5):283-6, 288.

25. Ghosh S, Mukhopadhyay U, Maji D, Bhaduri G. Visual impairment in urban school children of low-income families in Kolkata, India. Indian J Public Health. 2012;56(2):163-167. doi:10.4103/0019-557X.99919

26. Rao GN, Sabnam S, Pal S, Rizwan H, Thakur B, Pal A. Prevalence of ocular morbidity among children aged 17 years or younger in the eastern India. Clin Ophthalmol Auckl NZ. 2018;12:1645-1652. doi:10.2147/OPTH.S171822

27. Warkad VU, Panda L, Behera P, Das T, Mohanta BC, Khanna R. The Tribal Odisha Eye Disease Study (TOES) 1: prevalence and causes of visual impairment among tribal children in an urban school in Eastern India. J AAPOS. 2018;22(2):145.e1-145.e6. doi:10.1016/j. jaapos.2017.10.020

28. Panda L, Nayak S, Khanna RC, Das T. Tribal Odisha Eye Disease Study (TOES) \# 7. Prevalence of refractive error in children in tribal Odisha (India) school screening. Indian J Ophthalmol. 2020;68(8):1596-1599. doi:10.4103/ijo.IJO_2020_19

29. Padhye AS, Khandekar R, Dharmadhikari S, Dole K, Gogate P, Deshpande M. Prevalence of uncorrected refractive error and other eye problems among urban and rural school children. Middle East Afr J Ophthalmol. 2009;16(2):69-74. doi:10.4103/0974-9233.53864

30. Nangia V, Jonas JB, Sinha A, Matin A, Kulkarni M. Refractive error in central India: the Central India Eye and Medical Study. Ophthalmology. 2010;117(4):693-699. doi:10.1016/j.ophtha.2009.09.037

31. Jonas JB, Nangia V, Gupta R, Bhojwani K, Nangia P, Panda-Jonas S. Prevalence of myopic retinopathy in rural Central India. Acta Ophthalmol (Copenh). 2017;95(5):e399-404. doi:10.1111/aos.13301

32. Basu M, Das P, Pal R, Kar S, Desai VK, Kavishwar A. Spectrum of visual impairment among urban female school students of Surat. Indian J Ophthalmol. 2011;59(6):475-479. doi:10.4103/0301-4738.86317

33. Murthy GVS, Gupta SK, Ellwein LB, et al. Refractive error in children in an urban population in New Delhi. Invest Ophthalmol Vis Sci. 2002;43(3):623-631.

34. Saxena R, Vashist P, Tandon R, et al. Prevalence of myopia and its risk factors in urban school children in Delhi: the North India Myopia Study (NIM Study). PLoS One. 2015;10(2):e0117349. doi:10.1371/journal.pone.0117349

35. Shukla P, Vashist P, Singh SS, et al. Assessing the inclusion of primary school children in vision screening for refractive error program of India. Indian J Ophthalmol. 2018;66(7):935-939. doi:10.4103/ijo.IJO_1036_17

36. Ahmed I, Mian S, Mudasir S, Andrabi KI. Prevalence of myopia in students of Srinagar city of Kashmir, India. Int J Health Sci. 2008;2 (1):77-81.

37. Jha KN. Baseline ophthalmic data of school children aged 15 years or younger at Leh, Jammu and Kashmir, India. J Clin Diagn Res. 2008;64:1186-1190.

38. Singh NK, James RM, Yadav A, Kumar R, Asthana S, Labani S. Prevalence of myopia and associated risk factors in schoolchildren in North India. Optom Vis Sci. 2019;96(3):200-205. doi:10.1097/OPX.0000000000001344

39. Natung T, Taye T, Lyngdoh LA, Dkhar B, Hajong R. Refractive errors among patients attending the ophthalmology department of a medical college in North-East India. J Fam Med Prim Care. 2017;6(3):543-548. doi:10.4103/2249-4863.222023

40. Basu SK, Jindal A. Genetic aspects of myopia among the Shia Muslim Dawoodi Bohras of Udaipur, Rajsthan. Hum Hered. 1983;33 (3):163-169. doi:10.1159/000153369

41. Ratnamala U, Lyle R, Rawal R, et al. Refinement of the X-linked nonsyndromic high-grade myopia locus MYP1 on Xq28 and exclusion of 13 known positional candidate genes by direct sequencing. Invest Ophthalmol Vis Sci. 2011;52(9):6814-6819. doi:10.1167/iovs.10-6815

42. Sharmila F, Ramprabhu K, Kumaramanickavel G, Sudhir RR, Sripriya S, Sripriya S. Genetic analysis of axial length genes in high grade myopia from Indian population. Meta Gene. 2014;2:164-175. doi:10.1016/j.mgene.2014.01.004

43. Annamaneni S, Bindu CH, Reddy KP, Vishnupriya S. Association of vitamin D receptor gene start codon (Fok1) polymorphism with high myopia. Oman J Ophthalmol. 2011;4(2):57-62. doi:10.4103/0974-620X.83654

44. Gupta V, Somarajan BI, Walia GK, et al. Role of CYP1B1, p.E229K and p.R368H mutations among 120 families with sporadic juvenile onset open-angle glaucoma. Graefes Arch Clin Exp Ophthalmol. 2018;256(2):355-362. doi:10.1007/s00417-017-3853-0

45. Ahmed I, Rasool S, Jan T, Qureshi T, Naykoo NA, Andrabi KI. TGIF1 is a potential candidate gene for high myopia in ethnic Kashmiri population. Curr Eye Res. 2014;39(3):282-290. doi:10.3109/02713683.2013.841950

46. Rasool S, Ahmed I, Dar R, et al. Contribution of TGF $\beta 1$ codon 10 polymorphism to high myopia in an ethnic Kashmiri population from India. Biochem Genet. 2013;51(3-4):323-333. doi:10.1007/s10528-012-9565-6

47. Shukla P, Verma H, Patel S, Patra PK, Bhaskar LV. Ocular manifestations of sickle cell disease and genetic susceptibility for refractive errors. Taiwan J Ophthalmol. 2017;7(2):89-93. doi:10.4103/tjo.tjo_3_17

48. Verma M, Chhatwal J, Jaison S, Thomas S, Daniel R. Refractive errors in preterm babies. Indian Pediatr. 1994;31(10):1183-1186.

49. Kaur S, Sukhija J, Katoch D, Sharma M, Samanta R, Dogra MR. Refractive and ocular biometric profile of children with a history of laser treatment for retinopathy of prematurity. Indian J Ophthalmol. 2017;65(9):835-840. doi:10.4103/ijo.IJO_872_16

50. Kulkarni S, Shah M, Dole K, Taras S, Deshpande R, Deshpande M. Ocular outcomes and comorbidities in preterm infants enrolled for retinopathy of prematurity screening: a cohort study from western India. Oman J Ophthalmol. 2019;12(1):10-14. doi:10.4103/ojo. OJO_221_2017

51. Katoch D, Sanghi G, Dogra MR, Beke N, Gupta A. Structural sequelae and refractive outcome 1 year after laser treatment for type 1 prethreshold retinopathy of prematurity in Asian Indian eyes. Indian J Ophthalmol. 2011;59(6):423-426. doi:10.4103/0301-4738.86306

52. Anilkumar SE, Anandi V, Shah PK, Ganesh S, Narendran K. Refractive, sensory, and biometric outcome among retinopathy of prematurity children with a history of laser therapy: a retrospective review from a tertiary care center in South India. Indian J Ophthalmol. 2019;67 (6):871-876. doi:10.4103/ijo.IJO_2023_18

53. Sathar A, Abbas S, Nujum ZT, Benson JL, Sreedevi GP, Saraswathyamma SK. Visual outcome of preterm infants screened in a tertiary care hospital. Middle East Afr J Ophthalmol. 2019;26(3):158-162. doi:10.4103/meajo.MEAJO_64_17

54. Shah PK, Ramakrishnan M, Sadat B, Bachu S, Narendran V, Kalpana N. Long term refractive and structural outcome following laser treatment for zone 1 aggressive posterior retinopathy of prematurity. Oman J Ophthalmol. 2014;7(3):116-119. doi:10.4103/0974-620X.142592

55. Beri S, Malhotra M, Dhawan A, Garg R, Jain R, D'souza P. A neuroectodermal hypothesis of the cause and relationship of myopia in retinopathy of prematurity. J Pediatr Ophthalmol Strabismus. 2009;46(3):146-150. doi:10.3928/01913913-20090505-05 
56. Sanghi G, Dogra MR, Das P, Vinekar A, Gupta A, Dutta S. Aggressive posterior retinopathy of prematurity in Asian Indian babies: spectrum of disease and outcome after laser treatment. Retina Phila. 2009;29(9):1335-1339. doi:10.1097/IAE.0b013e3181a68f3a

57. Fielder AR, Quinn GE. Myopia of prematurity: nature, nurture, or disease? Br J Ophthalmol. 1997;81(1):2-3. doi:10.1136/bjo.81.1.2

58. Cook A, White S, Batterbury M, Clark D. Ocular growth and refractive error development in premature infants with or without retinopathy of prematurity. Invest Ophthalmol Vis Sci. 2008;49(12):5199-5207. doi:10.1167/iovs.06-0114

59. Jain D, Rathi H, Ambekar G, Nangia V. Glaucoma in myopia, its features and correlations: findings from Central India. Invest Ophthalmol Vis Sci. 2019;60(9):5566.

60. Mandal AK, Gothwal VK, Bagga H, Nutheti R, Mansoori T. Outcome of surgery on infants younger than 1 month with congenital glaucoma. Ophthalmology. 2003;110(10):1909-1915. doi:10.1016/S0161-6420(03)00671-7

61. Pan C-W, Cheung CY, Aung T, et al. Differential associations of myopia with major age-related eye diseases: the Singapore Indian Eye Study. Ophthalmology. 2013;120(2):284-291. doi:10.1016/j.ophtha.2012.07.065

62. Manayath GJ, Arora S, Parikh H, Shah PK, Tiwari S, Narendran V. Is myopia a protective factor against central serous chorioretinopathy? Int J Ophthalmol. 2016;9(2):266-270. doi:10.18240/ijo.2016.02.16

63. Praveen MR, Shah GD, Vasavada AR, Mehta PG, Gilbert C, Bhagat G. A study to explore the risk factors for the early onset of cataract in India. Eye Lond Engl. 2010;24(4):686-694.

64. Praveen MR, Vasavada AR, Jani UD, Trivedi RH, Choudhary PK. Prevalence of cataract type in relation to axial length in subjects with high myopia and emmetropia in an Indian population. Am J Ophthalmol. 2008;145(1):176-181. doi:10.1016/j.ajo.2007.07.043

65. Vanathi M, Tandon R, Titiyal JS, Vajpayee RB. Case series of 12 children with progressive axial myopia following unilateral cataract extraction. $J$ AAPOS. 2002;6(4):228-232. doi:10.1067/mpa.2002.123658

66. Jethani J, Kim U, Kharzei H, Vijayalakshmi P. Blepharophimosis syndrome and its association with amblyopia and refractive errors in a South Indian population. Asian J Ophthalmol. 2007;9:68-71.

67. Hussaindeen JR, Mani R, Agarkar S, Ramani KK, Surendran TS. Acute adult-onset comitant esotropia associated with accommodative spasm. Optom Vis Sci. 2014;91(4 Suppl 1):S46-S51. doi:10.1097/OPX.0000000000000182

68. Rutstein RP, Daum KM, Amos JF. Accommodative spasm: a study of 17 cases. J Am Optom Assoc. 1988;59(7):527-538.

69. Rutstein RP, Marsh-Tootle W. Acquired unilateral visual loss attributed to an accommodative spasm. Optom Vis Sci. 2001;78(7):492-495. doi:10.1097/00006324-200107000-00011

70. Faucher C, De Guise D. Spasm of the near reflex triggered by disruption of normal binocular vision. Optom Vis Sci. 2004;81(3):178-181. doi:10.1097/00006324-200403000-00009

71. Hussaindeen JR, Anand M, Sivaraman V, Ramani KK, Allen PM. Variant myopia: a new presentation? Indian J Ophthalmol. 2018;66 (6):799-805. doi:10.4103/ijo.IJO_1115_17

72. Merchant RH, Punde H, Thacker N, Bhatt D. Ophthalmic evaluation in beta-thalassemia. Indian J Pediatr. 2017;84(7):509-514. doi:10.1007/ s12098-017-2339-8

73. Nangia V, Jonas JB, Matin A, Kulkarni M, Sinha A, Gupta R. Body height and ocular dimensions in the adult population in rural Central India. The Central India Eye and Medical Study. Graefes Arch Clin Exp Ophthalmol. 2010;248(11):1657-1666. doi:10.1007/s00417-0101448-0

74. Chen ZT-Y, Wang I-J, Liao Y-T, Shih Y-F, Lin LL-K. Polymorphisms in steroidogenesis genes, sex steroid levels, and high myopia in the Taiwanese population. Mol Vis. 2011;17:2297-2310.

75. Gupta M, Rana SK, Mittal SK, Sinha RNP. Profile of amblyopia in school going (5-15 years) children at state level referral hospital in Uttarakhand. J Clin Diagn Res. 2016;10(11):SC09-SC11. doi:10.7860/JCDR/2016/16026.8866

76. Kemmanu V, Hegde K, Giliyar SK, Shetty BK, Kumaramanickavel G, McCarty CA. Prevalence of childhood blindness and ocular morbidity in a rural pediatric population in Southern India: the Pavagada Pediatric Eye Disease Study-1. Ophthalmic Epidemiol. 2016;23(3):185-192. doi:10.3109/09286586.2015.1090003

77. Mhaske MS, Khismatrao DS, Kevin F, Pandve HT, Kundap RP. Morbidity pattern and personal hygiene in children among private primary school in urban area: are the trends changing? J Fam Med Prim Care. 2013;2(3):266-269. doi:10.4103/2249-4863.120753

78. Kaur G, Thomas S, Jindal M, Bhatti SM. Visual function and ocular status in children with disabilities in special schools of Northern India. J Clin Diagn Res. 2016;10(10):NC01-4. doi:10.7860/JCDR/2016/23615.8742

79. Joshi RS, Somani AAK. Ocular disorder in children with mental retardation. Indian J Psychiatry. 2013;55(2):170-172. doi:10.4103/00195545.111457

80. Gogate P, Soneji FR, Kharat J, Dulera H, Deshpande M, Gilbert C. Ocular disorders in children with learning disabilities in special education schools of Pune, India. Indian J Ophthalmol. 2011;59(3):223-228. doi:10.4103/0301-4738.81036

81. Sheth PB, Shah HA, Dave JN. Periorbital hyperpigmentation: a study of its prevalence, common causative factors and its association with personal habits and other disorders. Indian J Dermatol. 2014;59(2):151-157. doi:10.4103/0019-5154.127675

82. Kumaran SE, Balasubramaniam SM, Kumar DS, Ramani KK. Refractive error and vision-related quality of life in South Indian children. Optom Vis Sci. 2015;92(3):272-278. doi:10.1097/OPX.0000000000000494

83. Rao YK, Padhye A, Midha T, Gupta A, Kumar A, Mohan K. Predictive value of headache for screening of refractive errors in the pediatric age group. J Pediatr Neurol. 2015;13(3):99-104. doi:10.1055/s-0035-1557146

84. Sivaraman V, Rizwana JH, Ramani K, et al. Near work-induced transient myopia in Indian subjects. Clin Exp Optom. 2015;98(6):541-546. doi: $10.1111 /$ cxo. 12306

85. Hedge SP, Dayanidhi VK. Study of pattern of change in handwriting class characters with different grades of myopia. J Clin Diagn Res. 2015;9 (12):HC01-04. doi:10.7860/JCDR/2015/15942.6960

86. Joseph L. Refractive errors and academic achievements of primary school children. Nurs J India. 2014;105(6):269-271.

87. Kesarwani P, Narang S, Chawla D, Jain S, Chandel M, Sood S. Vision-related quality of life in children with treated retinopathy of prematurity. Indian J Ophthalmol. 2019;67(6):932-935. doi:10.4103/ijo.IJO_323_19

88. Saxena R, Vashist P, Menon V. Is myopia a public health problem in India? Indian J Commun. 2013;38(2):83-85. doi:10.4103/09700218.112436 
89. Baskaran AA, Britto T, Rajkumar S, Thomas PA, Jesudasan CAN. Comparison of torsional amplitudes between emmetropes and myopes using after-image slides. Indian J Ophthalmol. 2019;67(5):655-658. doi:10.4103/ijo.IJO_1663_18

90. Kenia VP, Kenia RV, Pirdankar OH. Association between corneal biomechanical parameters and myopic refractive errors in young Indian individuals. Taiwan J Ophthalmol. 2020;10(1):45-53. doi:10.4103/tjo.tjo_15_19

91. Jonas JB, Bi HS, Wu JF, et al. Corneal curvature radius in myopia of schoolchildren versus adult myopia. Cornea. 2016;35(10):1333-1337. doi:10.1097/ICO.0000000000000854

92. Dhakal R, Vupparaboina KK, Verkicharla PK. Anterior sclera undergoes thinning with increasing degree of myopia. Invest Ophthalmol Vis Sci. 2020;61(4):6. doi:10.1167/iovs.61.4.6

93. Singh D, Mishra K, Agarwal E, Sharma R, Bhartiya S, Dada T. Assessment of retinal nerve fiber layer changes by cirrus high-definition optical coherence tomography in myopia. J Curr Glaucoma Pract. 2017;11(2):52-57. doi:10.5005/jp-journals-10028-1223

94. Dada T, Aggarwal A, Bali SJ, et al. Evaluation of retinal nerve fiber layer thickness parameters in myopic population using scanning laser polarimetry (GDxVCC). NEPJOPH. 2013;5(1):3-8. doi:10.3126/nepjoph.v5i1.7814

95. Malakar M, Askari SN, Ashraf H, Waris A, Ahuja A, Asghar A. Optical coherence tomography assisted retinal nerve fibre layer thickness profile in high myopia. J Clin Diagn Res. 2015;9(2):NC01-03. doi:10.7860/JCDR/2015/9054.5565

96. Biswas S, Biswas P. Longitudinal evaluation of the structural and functional changes associated with glaucoma in myopia. Optom Vis Sci. 2020;97(6):448-456. doi:10.1097/OPX.0000000000001519

97. Samuel NE, Krishnagopal S. Foveal and macular thickness evaluation by spectral OCT SLO and its relation with axial length in various degree of myopia. J Clin Diagn Res. 2015;9(3):NC01-04. doi:10.7860/JCDR/2015/11780.5676

98. Dhakal R, Goud A, Narayanan R, Verkicharla PK. Patterns of posterior ocular complications in myopic eyes of Indian population. Sci Rep. 2018;8(1):13700. doi:10.1038/s41598-018-29536-x

99. Kumar A, Chawla R, Kumawat D, Pillay G. Insight into high myopia and the macula. Indian J Ophthalmol. 2017;65(2):85-91. doi:10.4103/ijo. IJO_863_16

100. Matalia J, Anegondi NS, Veeboy L, Roy AS. Age and myopia associated optical coherence tomography of retina and choroid in pediatric eyes. Indian J Ophthalmol. 2018;66(1):77-82. doi:10.4103/ijo.IJO_652_17

101. Bhayana AA, Kumar V, Tayade A, Chandra M, Chandra P, Kumar A. Choroidal thickness in normal Indian eyes using swept-source optical coherence tomography. Indian J Ophthalmol. 2019;67(2):252-255. doi:10.4103/ijo.IJO_668_18

102. Venkatesh R, Jain K, Aseem A, Kumar S, Yadav NK. Intrachoroidal cavitation in myopic eyes. Int Ophthalmol. 2020;40(1):31-41. doi:10.1007/ s10792-019-01146-0

103. Marmamula S, Khanna RC, Narsaiah S, Shekhar K, Rao GN. Prevalence of spectacles use in Andhra Pradesh, India: rapid assessment of visual impairment project. Clin Experiment Ophthalmol. 2014;42(3):227-234. doi:10.1111/ceo.12160

104. Malhotra S, Kalaivani M, Rath R, et al. Use of spectacles for distance vision: coverage, unmet needs and barriers in a rural area of North India. BMC Ophthalmol. 2019;19(1):252. doi:10.1186/s12886-019-1262-3

105. Gupta V, Saxena R, Vashist P, et al. Spectacle coverage among urban schoolchildren with refractive error provided subsidized spectacles in North India. Optom Vis Sci. 2019;96(4):301-308. doi:10.1097/OPX.0000000000001356

106. Morjaria P, Bastawrous A, Murthy GVS, Evans J, Gilbert C. Effectiveness of a novel mobile health education intervention (Peek) on spectacle wear among children in India: study protocol for a randomized controlled trial. Trials. 2017;18(1):168. doi:10.1186/s13063-017-1888-5

107. Morjaria P, Evans J, Gilbert C. Predictors of spectacle wear and reasons for nonwear in students randomized to ready-made or custom-made spectacles: results of secondary objectives from a randomized noninferiority trial. JAMA Ophthalmol. 2019;137(4):408-414. doi:10.1001/ jamaophthalmol.2018.6906

108. Ravilla ST, Ramasamy D. Spectacle dispensing for myopia at primary eye care level. Community Eye Health. 2019;32(105):S3-4.

109. Singh K, Bhattacharyya M, Goel A, Arora R, Gotmare N, Aggarwal H. Orthokeratology in moderate myopia: a study of predictability and safety. J Ophthalmic Vis Res. 2020;15(2):210-217. doi:10.18502/jovr.v15i2.6739

110. Khan MA, Gupta A, Ahluwalia TS, Moulick PS, Gurunadh VS, Gupta S. A prospective interventional study of effect of accelerated orthokeratology on the corneal curvature and refraction among young adults with myopia. Med J Armed Forces India. 2016;72(2):125-130. doi:10.1016/j.mjafi.2016.02.016

111. Rajan R, Mahadevan R, Thomas AM, Bhattacharjee P. Contact lens trends over three decades in a hospital-based practice in India. Clin Exp Optom. 2018;101(2):182-187. doi:10.1111/cxo.12589

112. Chua W-H, Balakrishnan V, Chan Y-H, et al. Atropine for the treatment of childhood myopia. Ophthalmology. 2006;113(12):2285-2291. doi:10.1016/j.ophtha.2006.05.062

113. Chia A, Chua W-H, Cheung Y-B, et al. Atropine for the treatment of childhood myopia: safety and efficacy of $0.5 \%, 0.1 \%$, and $0.01 \%$ doses (Atropine for the Treatment of Myopia 2). Ophthalmology. 2012;119(2):347-354. doi:10.1016/j.ophtha.2011.07.031

114. Kothari M, Rathod V. Efficacy of $1 \%$ atropine eye drops in retarding progressive axial myopia in Indian eyes. Indian J Ophthalmol. 2017;65 (11):1178-1181. doi:10.4103/ijo.IJO_418_17

115. Saxena R, Dhiman R, Gupta V, et al. Atropine for the treatment of childhood myopia in India: multicentric randomized trial. Ophthalmology. 2021;128:1367-1369. doi:10.1016/j.ophtha.2021.01.026

116. Kothari M, Modak M, Khan H, Jahan S, Solanki M, Rathod V. Convergence excess consecutive esotropia associated with $0.01 \%$ atropine eye drops usage in patients operated for intermittent exotropia. Indian J Ophthalmol. 2020;68(4):653-656. doi:10.4103/ijo.IJO_1243_19

117. Kothari M, Jain R, Khadse N, Rathod V, Mutha S. Allergic reactions to atropine eye drops for retardation of progressive myopia in children. Indian J Ophthalmol. 2018;66(10):1446-1450. doi:10.4103/ijo.IJO_165_18

118. Tiwari NN, Sachdev GS, Ramamurthy S, Dandapani R. Comparative analysis of visual outcomes and ocular aberrations following wavefront optimized and topography-guided customized femtosecond laser in situ keratomileusis for myopia and myopic astigmatism: a contralateral eye study. Indian J Ophthalmol. 2018;66(11):1558-1561. doi:10.4103/ijo.IJO_507_18

119. Ganesh S, Brar S, Patel U. Comparison of ReLEx SMILE and PRK in terms of visual and refractive outcomes for the correction of low myopia. Int Ophthalmol. 2018;38(3):1147-1154. doi:10.1007/s10792-017-0575-6

120. Sanders DR, Doney K, Poco M; ICL in Treatment of Myopia Study Group. United States Food and Drug Administration clinical trial of the Implantable Collamer Lens (ICL) for moderate to high myopia: three-year follow-up. Ophthalmology. 2004;111(9):1683-1692. 
121. Igarashi A, Shimizu K, Kamiya K. Eight-year follow-up of posterior chamber phakic intraocular lens implantation for moderate to high myopia. Am J Ophthalmol. 2014;157(3):532-539.e1. doi:10.1016/j.ajo.2013.11.006

122. Titiyal JS, Sharma N, Mannan R, Pruthi A, Vajpayee RB. Iris-fixated intraocular lens implantation to correct moderate to high myopia in Asian-Indian eyes: five-year results. J Cataract Refract Surg. 2012;38(8):1446-1452. doi:10.1016/j.jcrs.2012.03.029

123. Sachdev GS, Singh S, Ramamurthy S, Rajpal N, Dandapani R. Comparative analysis of clinical outcomes between two types of posterior chamber phakic intraocular lenses for correction of myopia and myopic astigmatism. Indian J Ophthalmol. 2019;67(7):1061-1065. doi:10.4103/ ijo.IJO_1501_18

124. Sachdev G, Ramamurthy D. Long-term safety of posterior chamber implantable phakic contact lens for the correction of myopia. Clin Ophthalmol Auckl NZ. 2019;13:137-142. doi:10.2147/OPTH.S185304

125. Vasavada V, Srivastava S, Vasavada SA, Sudhalkar A, Vasavada AR, Vasavada VA. Safety and efficacy of a new phakic posterior chamber IOL for correction of myopia: 3 years of follow-up. J Refract Surg Thorofare NJ. 2018;34(12):817-823. doi:10.3928/1081597X-20181105-01

126. Bansal C. Comparative study on the effect of Saptamrita Lauha and Yoga therapy in myopia. Ayu. 2014;35(1):22-27. doi:10.4103/09748520.141904

127. Tiwari KK, Shaik R, Aparna B, Brundavanam R. A comparative study on the effects of vintage nonpharmacological techniques in reducing myopia (Bates eye exercise therapy vs. Trataka Yoga Kriya). Int J Yoga. 2018;11(1):72-76. doi:10.4103/ijoy.IJOY_59_16

128. Gopinathan G, Dhiman KS, Manjusha R. A clinical study to evaluate the efficacy of Trataka Yoga Kriya and eye exercises (non-pharmocological methods) in the management of Timira (Ammetropia and Presbyopia). Ayu. 2012;33(4):543-546. doi:10.4103/09748520.110534

129. Poonam RM, Manjusha R, Vaghela DB, Shukla VJ. A clinical study on the role of Akshi Tarpana with Jeevantyadi Ghrita in Timira (Myopia). Ayu. 2011;32(4):540-545. doi:10.4103/0974-8520.96130

\section{Publish your work in this journal}

Clinical Ophthalmology is an international, peer-reviewed journal covering all subspecialties within ophthalmology. Key topics include: Optometry; Visual science; Pharmacology and drug therapy in eye diseases; Basic Sciences; Primary and Secondary eye care; Patient Safety and Quality of Care Improvements. This journal is indexed on PubMed Central and CAS, and is the official journal of The Society of Clinical Ophthalmology (SCO). The manuscript management system is completely online and includes a very quick and fair peer-review system, which is all easy to use. Visit http://www. dovepress.com/testimonials.php to read real quotes from published authors. 